\title{
VALVE SELECTION FOR THE PURPOSE OF REDUCING THE WATER HAMMER EFFECT IN A PRESSURIZED PIPELINE
}

\author{
UDC 532.529:621.22
}

\author{
Milica Nikodijević ${ }^{1}$, Živojin Stamenković \\ Jelena Petrovićé, Miloš Kocić ${ }^{2}$ \\ ${ }^{1}$ University of Niš, Faculty of Occupational Safety, Niš, Serbia \\ ${ }^{2}$ University of Niš, Faculty of Mechanical Engineering, Niš, Serbia
}

\begin{abstract}
This paper discusses the gravity-fed hydraulic system, which consists of the upper reservoir, the lower reservoir, the pipeline, and valves. To achieve simpler and more efficient protection of a system against water hammer, it is advisable to establish conditions in which the pressure rises as little as possible during transient regimes without using any protective equipment. The discussion focuses on the pressure rise caused by different valve types: butterfly, needle, and ball valves, as well as two valve closure intervals -20 and 40 seconds. The systems considered have nominal diameters of DN 300 and DN 600. The problem was studied using a simulation of unsteady flow regimes of hydraulic transport. The obtained results regarding the maximum pressure rise due to water hammer were used to select the most satisfactory control valve for the considered hydraulic system.
\end{abstract}

Key words: water hammer, valve, simulation, pressure rise, valve closure time

\section{INTRODUCTION}

Every sudden flow change in a hydraulic system causes unsteady flow regimes. One of the unsteady, or transient, regimes is the water hammer. The phenomenon occurs due to a sudden change of the flow rate in a hydraulic system, which in turn leads to a change in pressure, which can be considerable under specific conditions. More elaborately, water hammer occurs when the fluid flow begins or stops suddenly or is forced to suddenly change direction accompanied by a change of intensity. Unsteady fluid flows have been studied ever since humans first directed the flow of water to accommodate their needs. Since then, for over a hundred years, the phenomenon has been the topic of numerous

Received November 6, 2018 / Accepted December 12, 2018

Corresponding author: Milica Nikodijević

University of Niš, Faculty of Occupational Safety in Niš, Čarnojevića 10a, 18000 Niš, Serbia

E-mail: milica.nikodijevic@znrfak.ni.ac.rs 
theoretical studies and practical considerations [1]. The first successful water hammer research was presented by the Italian engineer Lorenzo Allievi [2].

The water hammer effect is a common everyday occurrence, but people are not always aware of it. In most homes it happens daily, for instance when suddenly opening or closing various water taps. It also occurs in industries that utilize water, in water supply pipelines, in mine drainage systems, oil pipes, etc.

The practice of pressurized system maintenance has shown that the number of failures due to the water hammer effect is significant [3], although these cases are often not documented or analyzed in much detail. In addition, the repairs of the damage caused by water hammer require substantial material assets. Such failures, apart from having a damaging effect to the hydraulic system itself, can also exert a considerable negative environmental impact, especially when contaminant fluids are being transported. These are the chief reasons to find the way to mitigate the water hammer effect, i.e. to provide quality system operation control, where the changes in the hydraulic system are controlled, since unsteady flow regimes cannot be completely avoided.

Researchers have shown interest in finding methods to reduce the damaging effects of water hammer since the first time the effects were observed. Those methods usually involve the installation of additional devices in the hydraulic system. The majority of those safety devices are intended to maintain the pressure at an almost constant level at specified locations within the system or to maintain lower pressure than a preset value [4], [5], [6]. The criteria commonly prioritized when selecting safety devices include their efficiency, reliability, cost, and frequency of maintenance over a specified period [7]. There is a wide variety of safety mechanisms, but most of them can be classified into one of the following categories [8]: pipeline diameter increase; selection of valve type and valve opening/closing laws; pump inertia increase; surge tanks (regular, throttled, one way, etc.); water pressure vessels; pressure relief valves; check valves; bypass lines; etc.

Researchers are still working round the clock to analyze the existing and create new methods of protecting hydraulic systems from the water hammer effect. Thus, Shawn Batterton [9] used simulations to establish that the volumetric amount of air in a system is a relevant factor for water hammer control. Elbashir and Kwame [10] determined that stepwise valve closures can mitigate water hammer more prominently than linear valve closure. A number of authors have shown that a pump with a high inertia can also significantly reduce the effect of water hammer. Tan Wee Choon et al. [11] proved that prevention using the installation of a bypass line with a check valve reduces the water hammer effect, whereby pressure rise is reduced by $33.33 \%$. Nashat A. Ali et al. [12] analyzed different water hammer protection methods for a water supply network. They showed that the use of surge tanks, pressure tanks, and bypass lines with a check valve can efficiently protect pipelines from water hammer. Goran Gjetvaj and Martina Tadić [13] studied the contribution of elastic forces on pressure increase in pipelines protected by a pressure tank (air vessel). Andrey Ragalev et al. [14] focused on analyzing the impact of undissolved air containing liquid in order to diminish the water hammer effect. For this purpose, they proposed injection of air into the pipe, whereby the optimal volume concentration of air does not exceed 5\%. This protection method works best when applied to pressurized systems for wastewater drainage. Apoloniusz Kondura [15] showed that the water hammer effect depends greatly on the characteristics of butterfly valve closure. Yanfei Kon et al. [16] studied a water hammer protection method for mine drainage. They proposed a system that is based on adjusting the speed of the hydraulic control valve 
jumper. Wuyi Wan and Boran Zhang [17] investigated the water hammer protection of a water supply pipeline by means of an intelligent self-controlled surge tank. Using simulations and analyses, they proved that this surge tank has improved applicability over conventional tanks.

Previous studies unequivocally demonstrate that every pressurized pipeline needs to have a safety system against the water hammer effect. Typically, all water hammer safety systems for pipelines increase the propagation time of water hammer waves [18].

Every designer of pressurized hydraulic systems has to pay special attention to the selection of components. They should be selected so as to minimize the intensity of water hammer when no safety equipment is installed. This is understandable, since it is easier to protect a system against lower water hammer intensities. The designer is able to choose some of the components, but some of them are defined by the terms of reference, conditions in the field, and the laws. One component designers can choose the pipeline shutoff valve, a wide array of which is available on the market. In order to define the recommendations for pressurized hydraulic system design, this paper examines three valve types. The goal was to determine which valve type causes the minimal water hammer effect. The study was performed using numerical simulations of unsteady operational regimes of hydraulic systems.

\section{ANALYZED VALVE TYPES}

Out of a vast variety of valves available on the market, this study considers the following types: butterfly, needle, and ball valves. Before the examination of these valves, brief descriptions of the three valve types are given below. Figure 1 shows a typical butterfly valve and Figures $2 \mathrm{a}$ and $2 \mathrm{~b}$ show flow coefficient diagrams of these valves with a $300 \mathrm{~mm}$ and 600 $\mathrm{mm}$ diameter, respectively, obtained through the analysis of data collected from different manufacturers.

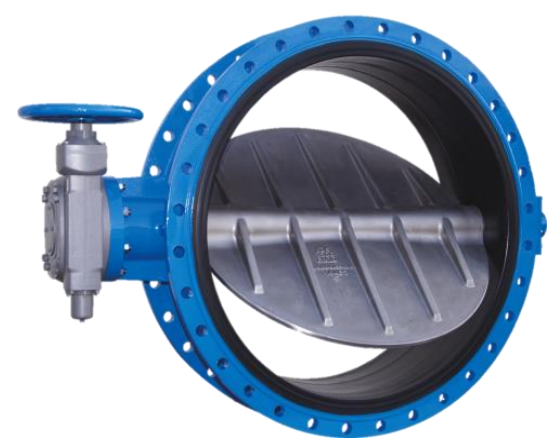

Fig. 1 Typical design and construction of butterfly valves 


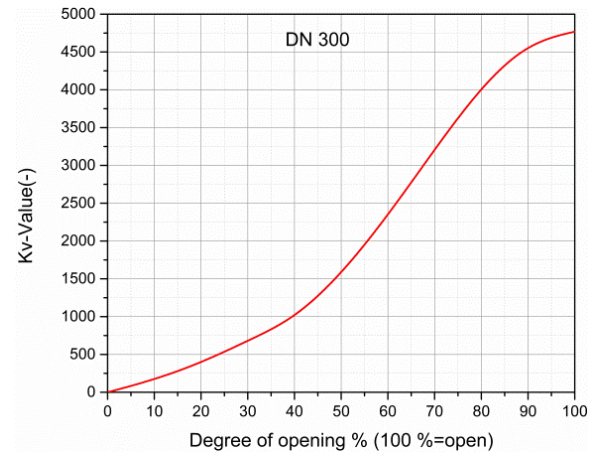

(a)

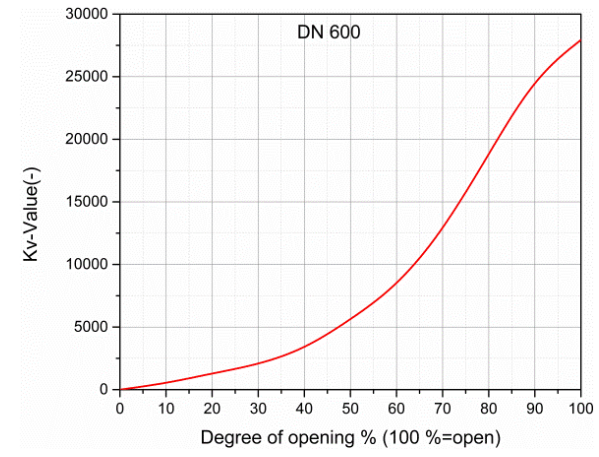

(b)

Fig. 2 Butterfly valve flow coefficient depending on the degree of opening

Butterfly valves can initiate, stop, or limit the flow in a system. They are compactly built, with high control capability, they can be installed in any position, and they are easy to maintain. Due to such properties, they are widely used in drinking water production, preparation, and distribution systems, energy systems, irrigation systems, chemical and process industries, shipbuilding, etc.

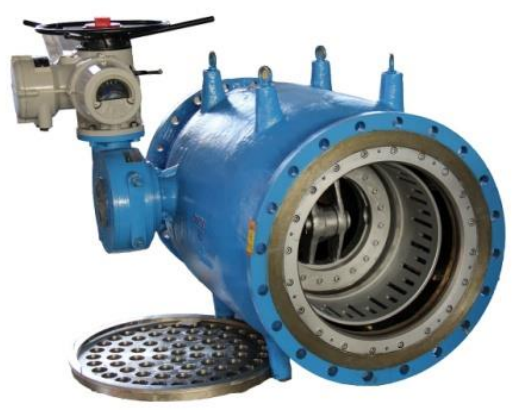

(a)

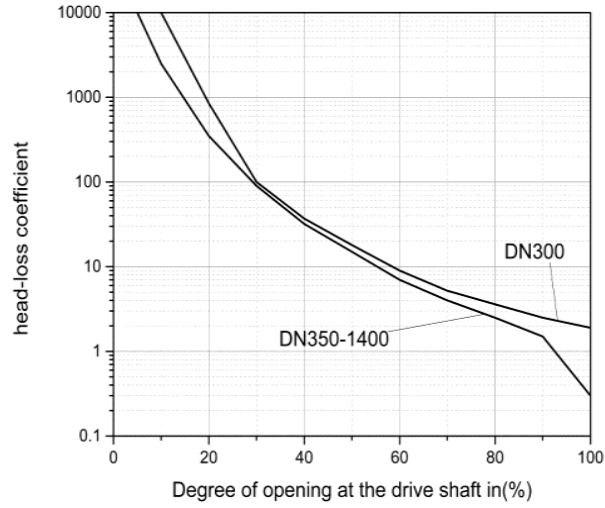

(b)

Fig. 3 (a) Needle valve, (b) Head loss coefficient depending on the degree of opening

A typical needle (piston ring) valve is shown in Figure 3a, while its head loss coefficient $\zeta$ is shown in Figure 3b. These valves are mainly used when the pressure/flow needs to be reduced and controlled reliably. They are used to initiate, stop, and regulate the flow in a pipeline.

Their construction allows them to precisely control the volumetric flow of liquids passing through the valve. 
Since most manufacturers possess the head loss coefficient data for these valves, we first created the diagrams of head loss coefficients as functions of the degree of opening. For these diagrams for coefficient $\zeta$ of valves with nominal diameters DN300 and DN600, the formula:

$$
\mathrm{K}_{\mathrm{V}}=0.0396 \frac{\mathrm{D}^{2}}{\sqrt{\zeta}}
$$

where $\mathrm{D}$ is the pipe diameter $[\mathrm{mm}]$ is used to determine the values of the flow coefficient $K_{V}\left[\mathrm{~m}^{3} / \mathrm{h}\right]$, which are required for the numerical simulations of water hammer in the pipeline.

The flow coefficient $K_{V}\left[\mathrm{~m}^{3} / \mathrm{h}\right]$ for all considered valve types is defined with the following expression:

$$
K_{\mathrm{V}}=\mathrm{Q} \sqrt{\frac{\rho}{1000 \Delta \mathrm{p}}}
$$

where: Q $\left[\mathrm{m}^{3} / \mathrm{h}\right]$ - flow, $\Delta \mathrm{p}[\mathrm{bar}]-$ valve pressure drop, and $\rho\left[\mathrm{kg} / \mathrm{m}^{3}\right]$ - density of the fluid.

One of the variants of a ball valve is shown in Figure 4 in three positions, whereas the table 1 represents $\mathrm{C}_{\mathrm{V}}$ coefficient values for these valves.

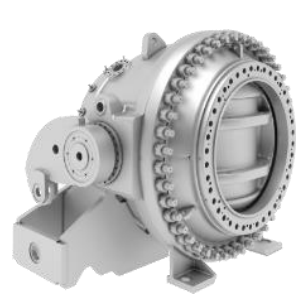

(a)

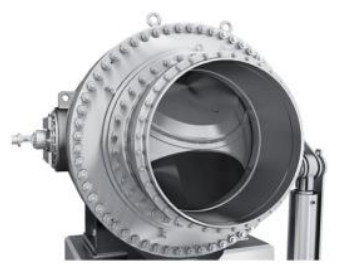

(b)

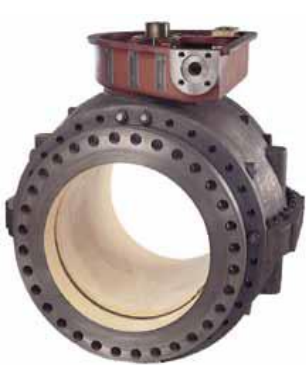

(c)

Fig. 4 Ball valve: (a) fully closed; (b) 50\% stroke; (c) fully open

Ball valves contain a hollow pivoting ball. They are used to initiate, regulate, and stop the flow, and are characterized by impermeable and durable sealing, even under very high pressures. They are a good choice for pipeline shutoff and control, but their performance is lacking in fine control applications. They are also simple to use and easy to maintain.

The table 1 provides the values for the imperial unit flow coefficient $\mathrm{C}_{\mathrm{V}}$, common in the Anglo-World. Most of the literature, however, uses the metric flow coefficient $\mathrm{K}_{\mathrm{V}}$. Flow coefficients $C_{V}$ and $K_{V}$ are defined using the same expression (2), the difference being that the Anglo-American literature uses US gallons per minute (gal/min) for flow rate, pounds per square inch (psi) for pressure, and $\mathrm{kg} / \mathrm{dm} 3$ for density. Thus, the relation between the two coefficients can be represented as follows:

$$
\mathrm{C}_{\mathrm{V}}=1.168 \mathrm{~K}_{\mathrm{V}}
$$


Table 1 Approximate $\mathrm{Cv}$ values of ball valves for different degrees of opening

\begin{tabular}{crrrrrr}
\hline \multicolumn{7}{c}{ Approximate CV values } \\
\hline Valve Size $(\mathrm{mm})$ & \multicolumn{1}{c}{$5^{\mathbf{0}}$} & \multicolumn{1}{c}{$10^{\circ}$} & \multicolumn{1}{c}{$30^{\mathbf{0}}$} & \multicolumn{1}{c}{$50^{\circ}$} & \multicolumn{1}{c}{$70^{\circ}$} & Fully Open \\
\hline 200 & 61 & 124 & 401 & 859 & 1.853 & 6.688 \\
300 & 137 & 280 & 902 & 1.934 & 4.170 & 19.300 \\
400 & 245 & 497 & 1.605 & 3.440 & 7.414 & 34.400 \\
500 & 382 & 777 & 2.508 & 5.375 & 11.586 & 59.900 \\
600 & 550 & 1.119 & 3.612 & 7.740 & 16.683 & 88.900 \\
900 & 1.238 & 2.517 & 8.126 & 17.413 & 37.535 & 222.000 \\
\hline
\end{tabular}

\section{METHODOLOGY AND RESULTS}

The simulation of the water hammer that initiates valve closure uses a simple hydraulic system, as shown in Figure 6. The system consists of the open upper reservoir (J1), in which the water level is $70 \mathrm{~m}$ above the water level in the open lower reservoir (J3), the valve (J2) at a height of $5 \mathrm{~m}$, a $2000 \mathrm{~m}$ long pipe (P1) in front of the valve, and a $25 \mathrm{~m}$ long pipe (P2) behind the valve. Water temperature is $15^{\circ} \mathrm{C}$.

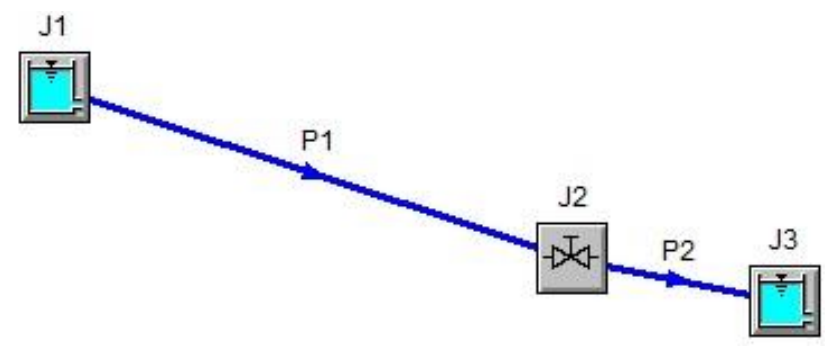

Fig. 6 Hydraulic system

In practice, valve opening and closure are never instantaneous but unfold over a time interval, however short it might be. This study considers closure intervals of 20 and 40 seconds for all valves. Likewise, simulations for all valves were performed for nominal diameters of $300 \mathrm{~mm}$ and $600 \mathrm{~mm}$, for the aforementioned closure times; simulations were performed only for steel water transport pipes.

Figures 7, 8, and 9 show the diagrams of water hammer simulation for a DN 300 pipe and $20 \mathrm{~s}$ valve closure time for the butterfly, needle, and ball valve, respectively. The results are combined in Figure 10 for easier comparison.

Figure 7 reveals that the installation of a butterfly valve with a $20 \mathrm{~s}$ closure in the hydraulic system shown in Figure 6 causes the pressure rise of $\Delta p=43.33$ bar during water hammer. If a needle valve with the same closure time (Fig.8) is installed into the hydraulic system, the pressure rise will reach $\Delta \mathrm{p}=30.59$ bar during water hammer. Finally, a ball valve with a 20 s closure time (Fig.9), the pressure rises to $\Delta p=29.71$ bar during water hammer. 


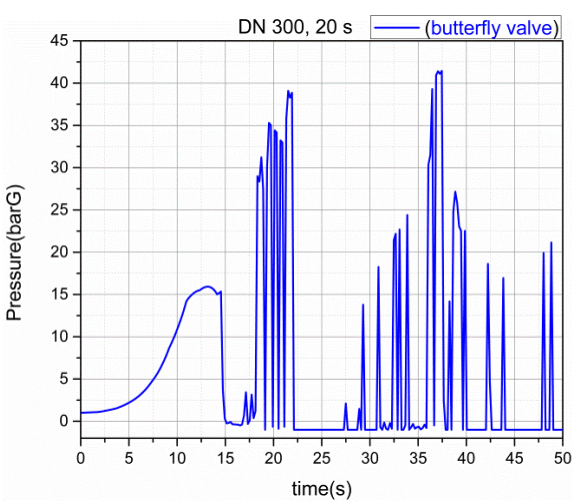

Fig .7 Pressure change over time (butterfly valve, DN 300,20 s)

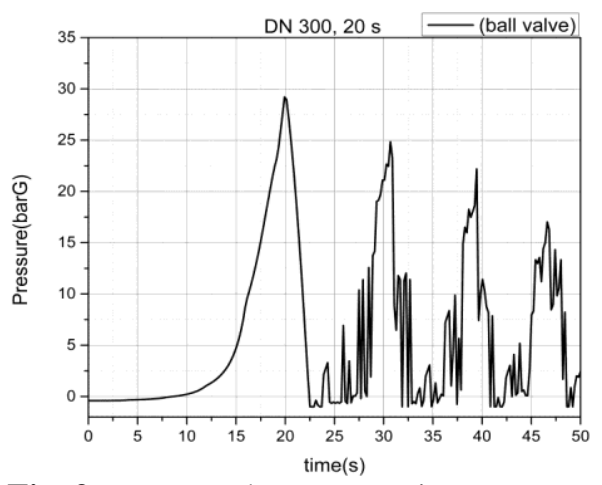

Fig. 9 Pressure change over time (ball valve, DN 300, 20 s)

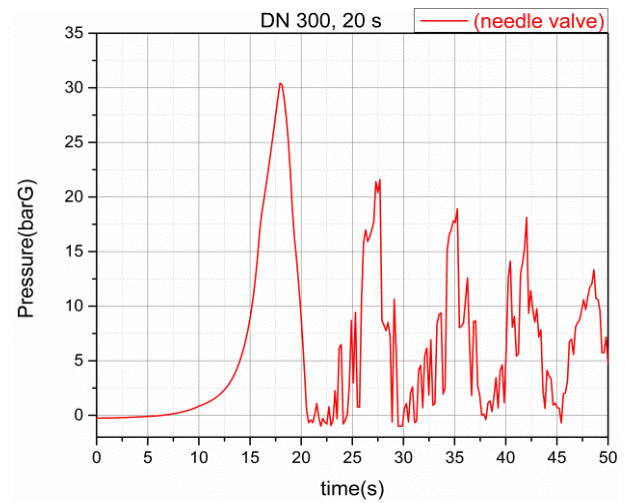

Fig. 8 Pressure change over time (needle valve, DN 300, 20 s)

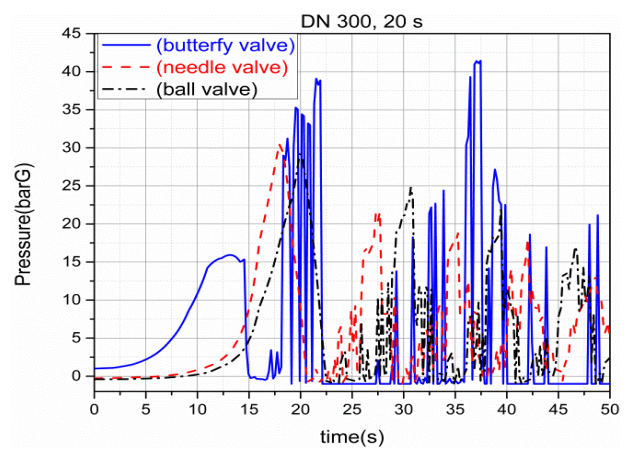

Fig. 10 Pressure change over time (all analyzed valve types, DN 300, 20 s)

For a more compact and efficient representation of the study results, the results obtained for the same pipe diameter and the same valve closure interval will be combined in a single diagram. Thus, Figure 11 shows the results for a DN 600 pipe with 20 s closure time for all three valve types: the water hammer induced pressure rise is $\Delta \mathrm{p}=50$ bar with a butterfly valve installed, $\Delta \mathrm{p}=38.82$ bar with a needle valve, and $\Delta \mathrm{p}=33.91$ bar with a ball valve. The corresponding pressure rises for a smaller pipe diameter are lower, as expected.

The results presented so far and shown in Figures 10 and 11 lead to a conclusion that, barring other limitations, it is best to install a ball valve with a 20 s closure time, because it will ensure the lowest pressure rise in the system due to water hammer. 


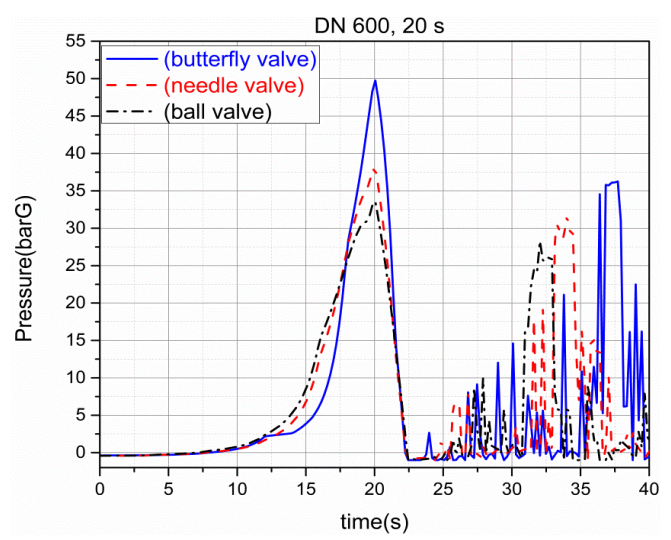

Fig.11 Pressure change over time (butterfly, needle, and ball valve, DN 600, 20s)

Figures 12 and 13 show the pressure envelopes for all valve types considered, with pipe diameters DN 300 and DN 600, respectively, and the valve closure time of 20 seconds.

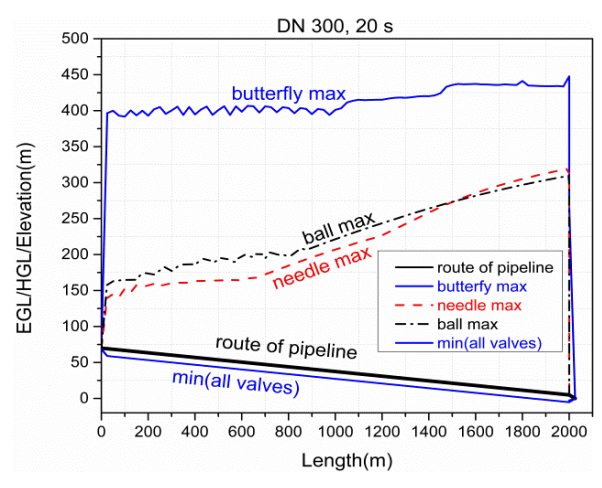

Fig. 12 Maximum and minimum pressure envelopes (for all analyzed valve types, DN 300, 20 s)

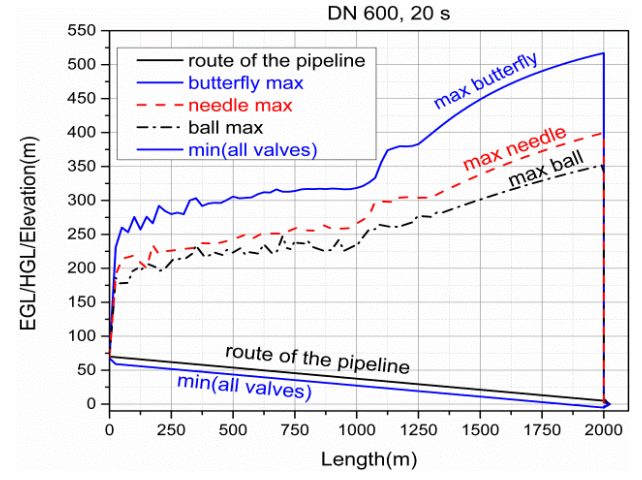

Fig. 13 Maximum and minimum pressure envelopes (for all analyzed valve types, DN 600, $20 \mathrm{~s}$ )

The diagrams clearly indicate that high vacuums occur inside the pipe (minimum pressure envelopes either intersect or go below the route of the pipeline), which may cause water column separation and yet another water hammer. Naturally, this closure time is not allowed, which leads to a conclusion that it is not recommended, although it has already been determined that the installation of a $20 \mathrm{~s}$ closure ball valve will yield the lowest pressure.

Figures 14 and 15 show the results of water hammer simulation in the considered hydraulic system for DN 300 and DN 600 pipe diameters, but this time for a 40 s closure time of all analyzed valve types. 


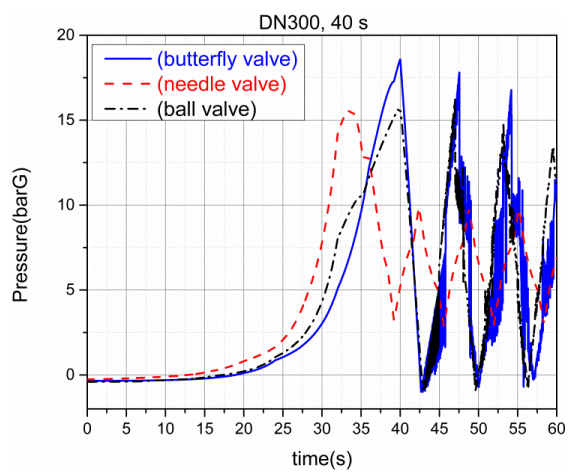

Fig. 14 Pressure change over time (butterfly, needle, and ball valve, DN 300, $40 \mathrm{~s}$ )

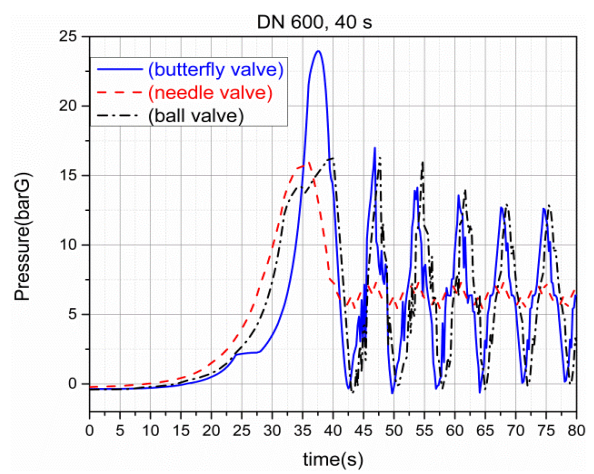

Fig. 15 Pressure change over time (butterfly, needle, and ball valve, DN 600, $40 \mathrm{~s}$ )

Figure 14 reveals that installing a butterfly valve with a 40 s closure time in the analyzed system with a DN 300 pipe in front of the valve would result in a pressure rise of $\Delta \mathrm{p}=18.33$ bar during water hammer. Pressure rise with a needle valve is $\Delta \mathrm{p}=15.56$ bar, while with a needle valve it is $\Delta \mathrm{p}=15.87$ bar. Barring other limitations, a needle valve is the most suitable option for this particular system, as it will provide the lowest water hammer pressure. Figure 15 shows that installing a valve with a $40 \mathrm{~s}$ closure time in the system, this time with a DN 600 pipe, will result in the following pressure rises: $\Delta p=$ 24 bar for a butterfly valve, $\Delta \mathrm{p}=15.88$ bar for a needle valve, and $\Delta \mathrm{p}=16.52$ bar for a ball valve. This pipe diameter also favours the installation of a needle valve.

Figures 16 and 17 show pressure envelopes for all analyzed valve types with a closure time of $40 \mathrm{~s}$, for pipe diameters DN 300 and DN 600, respectively.

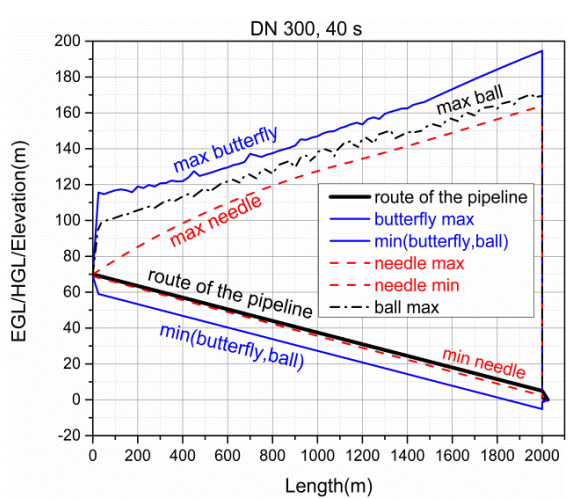

Fig. 16 Maximum and minimum pressure envelopes (for all analyzed valve types, DN 300, $40 \mathrm{~s}$ )

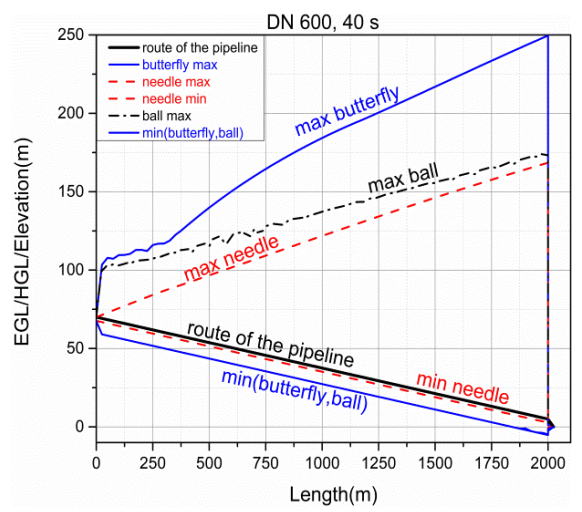

Fig.17 Maximum and minimum pressure envelopes (for all analyzed valve types, DN 600, $40 \mathrm{~s}$ ) 
Both diagrams confirm the previous conclusion that a needle valve is the best option for the lowest rise with a $40 \mathrm{~s}$ valve closure time.

The results presented above indicate that the considered hydraulic system would be best served by a needle valve with a $40 \mathrm{~s}$ closure time. This in turn suggests that designers have to consider the specific system and valve closure times in advance. They subsequently need to analyze the water-hammer initiated pressure rise and the probability of water column separation (case when envelopes of minimal pressure are lower than pipeline elevation) and local sub-pressures for each valve option before selecting the right one.

\section{CONCLUSION}

This paper analyzed the performance of different valve types in the specified hydraulic system in order to determine the best valve option in terms of pressure reduction during water hammer. It was established that valves with a $20 \mathrm{~s}$ closure time are not recommended for the given system, as they can potentially cause water column separation and further instances of water hammer. In case of valves with a $40 \mathrm{~s}$ closure time, a needle valve was found to be the most suitable for the given system. These conclusions pertain to nominal pipe diameters of both $300 \mathrm{~mm}$ and $600 \mathrm{~mm}$.

\section{REFERENCES}

1. Menabrea, L. F., 1885, Note sur les effects de choc de l' eau dans les conduites, C. R. Hedb. Seances Acad. Sci. 47, July - Dec., pp. 221-224

2. Lorenzo Allievi, 1903, Teoria generale del moto pertubato dell'acqua ani tubi in pressione, Ann. Soc. Ing. Arch. Italiana (French translation by Allievi 1904 Revue mecanique)

3. Ilin J. A., 1987, Calculations of water systems, Stroizdat, Moscow (in Russian)

4. Chaudhry M. H., 1987, Applied hydraulic transient, Second edition Ed., Van Nostrand Reinhold Company Inc., New York

5. Streeter V. L. and Wylie E. B., 1973, Water hammer and surge control, Annual review fluid mechanics, 6, pp. 57-73

6. Nabi G., Habib-ur-Rehman, Kashif M. and Tareq M., 2011, Hydraulic transient analysis of surge tanks: case study of Satpara and GoldenGol Hydropower projects in Pakistan, Pak. J. Engg. and Apple Sci, 8, pp. $34-48$

7. Wylie E. B. and Streeter V. L., 1983, Fluid transients, Corrected edition Ed., Thomson - Shore, Dexter, MI, United States of America

8. Ivetić M.V., 1996, Računska hidraulika Tečenje u cevima, Građevinski fakultet Univerziteta u Beogradu

9. Batterton S., 2006, Water Hammer: An Analysis of Plumbing Systems, Instruction, and Pump Operation, Master thesis, Faculty of the Virginia Polytechnic Institute and State University, Blackburg, Virginia

10. Mosab A. Magyoub Elbashir, Saumuel Oduro Kwame Amoah, 2007, Hydraulic transient in a pipeline using computer model to calculate and simulate transient, Master thesis, Division of Water Resources Engineering, Department of Building and Environmental Technology, Lund University, Sweden

11. Tan Wee Choon, Lim Kheng Aik, Lim Eng Aik, Teoh Thean Hin, 2012, Investigation of Water Hammer Effect Through Pipeline System, International Journal on Advanced Science Engineering Information Technology, Vol. 2, No. 3, pp. 47-53

12. Nashat A.Ali., Gamal Abozeid and Moustafa S. Darweesh, 2013, Analysis of different protection methods against water hammer on water supply network (Case study - Assiut city network), Journal of Engineering Sciences Assiut University, Faculty of Engineering, Volume 41, No. 6, pp. 2021-2035

13. Goran Gjetvaj, Martina Tadić, 2014, The effect of water hammer on pressure increases in pipelines protected by an air vessel, Tehnički vjesnik 21,3 , pp. 479-484

14. Andrey Rogalev, Anna Kocherova, Ivan Komarov, Ivan Garanin, Galina Kurdiukova, 2015, Ways of Protection of Pipeline Systems against Hydraulic Hammer, Contemporary Engineering Sciences, Vol. 8, No. 23, pp. 1067-1081 
15. Apoloniusz Kodura, 2016, An Analysis of the Impact of Valve Closure Time on the Course of Water Hammer, Archives of Hydro-Engineering and Environmental Mechanics, Vol. 63, No. 1, pp. 35-45

16. Yanfei Kou, Jieming Yang and Ziming Kou, 2016, A Water Hammer Protection Method for Mine Drainage System Based on Velocity Adjustment of Hydraulic Control Valve, Hindawi Publishing Corporation Shock and Vibration, Vol. 2016, Article ID 2346025, 13 pages

17. Wuyi Wan and Boran Zhang, 2018, Investigation of Water Hammer Protection in Water Supply Pipeline System Using an Intelligent Self - Controlled Surge Tank, Energies, Vol.11, (in the press)

18. Nenad Bolf, 2017, Mjerna i regulacijska tehnika, Kem. Ind. 66 (11-12), pp. 713-715

\section{IZBOR VENTILA U CILJU SMANJENJA EFEKTA HIDRAULIČKOG UDARA U CEVOVODU POD PRITISKOM}

U radu se razmatra hidraulički sistem koji se sastoji od gornjeg rezervoara, donjeg rezervoara, cevovoda $i$ ventila. Zbog jednostavnije i jeftinije zaštite sistema od hidrauličkog udara dobro je da je porast pritiska, pre korišćenja zaštitne opreme, što manji. Razmatra se porast pritiska koji izazivaju različite vrste ventila $i$ to leptirasti, igličasti $i$ loptasti kao $i$ dva interval vremena zatvaranja ventila 20 i 40 sekundi. Razmatrani su sistemi kod kojih je nominalni prečnik cevi 300 $\mathrm{mm}$ i $600 \mathrm{~mm}$. Problem je izučavan korišćenjem simulacije hidrauličkog udara. Na osnovu dobijenih rezultata za maksimalni porast pritiska pri hidrauličkom udaru izvršen je izbor najpovoljnijeg ventila za razmatrani hidraulički sistem.

Ključne reči: hidraulički udar, ventil, simulacija, porast pritiska, vreme zatvaranja ventila 